\title{
Interspecies interactions mediated by conductive minerals in the sediments of the Iron rich Meromictic Lake La Cruz, Spain
}

\author{
Amelia-Elena Rotaru, ${ }^{1,}$, Nicole R. Posth ${ }^{2}$, Carolin R. Löscher ${ }^{1,3}$, Maria R. Miracle ${ }^{4, \dagger}$, Eduardo \\ Vicente $^{4}$, Raymond P. Cox ${ }^{5}$, Jennifer Thompson ${ }^{6}$, Simon W. Poulton ${ }^{6}$ and Bo Thamdrup ${ }^{1}$ \\ ${ }^{1}$ Department of Biology, University of Southern Denmark, Campusvej 55, 5230 Odense, DK. \\ 2 Department of Geosciences and Natural Resource Management (IGN), Geology, University of Copenhagen, \\ Øster Voldgade 10, 1350 Copenhagen, DK. \\ 3 Danish Institute for Advanced Science, University of Southern Denmark, Campusvej 55, 5230 Odense, DK. \\ ${ }^{4}$ Instituto Cavanilles de Biodiversidad y Biología Evolutiva, University of Valencia, 46980 Paterna, Spain. \\ 5 Department of Biochemistry and Molecular Biology, University of Southern Denmark, Campusvej 55, 5230 \\ Odense, DK. \\ 6 School of Earth and Environment, University of Leeds, Leeds, LS2 9JT, UK. \\ $\dagger$ Deceased. This article is in memoriam of Professor Maria R. Miracle. \\ * Corresponding author: arotaru@biology.sdu.dk
}

Received: 09/08/18 Accepted: 22/11/18

\begin{abstract}
Interspecies interactions mediated by conductive minerals in the sediments of the Iron rich Meromictic Lake La Cruz, Spain

Lake La Cruz is considered a biogeochemical analogue to early Earth marine environments because its water column is depleted in sulfate, but rich in methane and iron, similar to conditions envisaged for much of the Precambrian. Here we show that conductive particles drove the metabolic coupling between electroactive microbial clades from this environment. The anoxic sediment of Lake La Cruz was rich in biogeochemically 'reactive' iron minerals, and harbored known electroactive species such as Geobacter and Methanothrix, in addition to groups never linked to an electroactive lifestyle. Slurry incubations on various substrates in the presence of conductive particles showed 2 to 4 times higher methanogenic activity, as compared to incubations with non-conductive glass beads or without added particles. In the absence of conductive particles, all tested substrates were metabolized to acetate, which accumulated above $8 \mathrm{mM}$ depending on substrate $(8 \pm 0.6$ to $11.7 \pm 1.2 \mathrm{mM})$. Only by enabling syntrophic acetate oxidation with conductive minerals could we prevent acetate accumulation. Acetate oxidation conductively coupled to methanogenic activity had a stoichiometric recovery of $70 \%$ and could be maintained in subsequent transfers only if amended with conductive particles. Mud-free enrichments without conductive particles ceased any metabolic activity after the second transfer. Conductive particles preserved a consortium of Youngiibacter-Methanothrix, whereas without conductive particles Youngiibacter spp. died off. Syntrophic consortia from this early Earth analogue environment only survived in the presence of conductive particles inferring that minerals may have arbitrated the earliest interspecies associations.
\end{abstract}

Key words: Methanothrix, Geobacter, Youngiibacter, magnetite, conductive particles, granular activated carbon, direct interspecies electron transfer, mineral mediated syntrophy, iron meromictic lake

\section{RESUMEN}

Interacciones interespecíficas mediadas por minerales conductivos en el sedimento del Lago La Cruz (España), un lago meromíctico rico en hierro

La laguna de La Cruz puede considerarse como un análogo biogeoquímico de los ambientes marinos en la Tierra primitiva, porque su columna de agua, muy escasa en sulfato pero rica en metano y hierro, presenta condiciones similares a estos ambientes en el Precámbrico. En este ambiente encontramos que partículas conductivas establecen un acoplamiento metabólico 
entre clados microbianos electroactivos. Demostraremos que el sedimento anóxico de la laguna de La Cruz, rico en minerales de hierro biogeoquímicamente "reactivos", alberga conocidas especies electroactivas tales como Geobacter y Methanothrix, además de otros grupos microbianos que no han sido previamente asociados con un estilo de vida electroactivo. Las incubaciones de lodo en varios sustratos realizadas en presencia de partículas conductivas tuvieron como resultado una actividad metanogénica de dos a cuatro veces mayor, comparadas con las incubaciones con microperlas de vidrio no conductivas o sin partículas adicionadas. En ausencia de particulas conductivas, todos los sustratos probados fueron metabolizados a acetato, que se acumulaba hasta una concentración de hasta aproximadamente $8 \mathrm{mM}$ dependiendo del sustrato ( $8 \pm 0.6$ to $11.7 \pm 1.2 \mathrm{mM})$. Sólo la adición de mineral conductivo a los lodos de la laguna de La Cruz hacía posible la oxidación del acetato, impidiendo su acumulación. La oxidación del acetato acoplada a una alta actividad metanogénica tuvo una recuperación estequiométrica del $70 \%$ y pudo mantenerse en sucesivos enriquecimientos libres de sedimento solo si estos se adicionaban con minerales conductivos. Por el contrario, enriquecimientos libres de sedimento y sin partículas conductivas cesaron cualquier actividad metabólica en la segunda transferencia de la serie. Las partículas conductivas conservaron la existencia del consorcio Youngiibacter-Methanothrix, mientras que Youngiibacter spp. muere y desaparece en ausencia de las particulas conductivas. Consorcios sintróficos de este ambiente análogo al de la Tierra primitiva sólo sobrevivieron en presencia de partículas conductivas infiriendo que los minerales pueden haber mediado en las asociaciones interespecíficas más primitivas.

Palabras clave: Methanothrix, Geobacter, Youngiibacter, magnetita, partículas conductivas, carbón activo granulado, transferencia directa de electrones interespecifica,sintrofia con mediación mineral, lago meromíctico ferruginoso

\section{INTRODUCTION}

It has been proposed that eukaryotic life arose from syntrophic interactions between Deltaproteobacteria and methanogenic archaea (Moreira \& Lopez-Garcia, 1998; López-García \& Moreira, 1999; Martin \& Russell, 2003) in the anoxic and ferruginous (Fe-rich) early Archaean ocean (Crowe et al., 2008). Similar conditions exist today in the anoxic deeper waters of some lakes (Crowe et al. 2008; Bura-Nakic et al., 2009; Llirós et al., 2015), including Lake La Cruz, Spain (Walter et al., 2014; Camacho et al., 2017). Most studies of these environments have focused on the phototrophic and methanotrophic communities in the water column, yet little attention has been given to either the methanogenic community buried in the sediments or the possible impact of iron-minerals on their physiology. Only recently, have researchers investigated the methanogenic community from Lake Matano, Indonesia which displayed high methanogenic rates when spiked with the iron-oxide, goethite (Bray et al., 2017). However, the possibility of a mineral-mediated syntrophic interaction was not assessed.

Generally, syntrophic associations are carried out indirectly, in which case electron transfer between partners is assisted by diffusible chemicals $\left(\mathrm{H}_{2}\right.$, formate, shuttles). These classical syntrophic interactions require a bacterium and a methanogenic archaeon as syntrophic partner.
The bacterium oxidizes complex organics to reduced compounds (i.e. $\mathrm{H}_{2}$ ), that are then retrieved by the methanogenic archaeon in order to reduce $\mathrm{CO}_{2}$ to methane (Shrestha \& Rotaru, 2014). Recent studies have shown that, sometimes, interspecies electron transfer does not require a diffusible chemical carrier. In the absence of a diffusible electron carrier, interspecies electron transfer could occur via conductive particles (magnetite, chars, pyrite) (Liu et al., 2012; Chen et al., 2014; Liu et al., 2015; Kato \& Igarashi, 2018; Wang et al., 2018) or directly by forging electric connections via a self-assembled extracellular network of conductive pili and $c$-type cytochromes between the two syntrophic partners (Summers et al., 2010; Rotaru et al., 2014b, 2014a). The later is known as direct interspecies electron transfer (DIET). DIET was shown to be accelerated by conductive materials possibly because cells save energy by pausing the production of their own conductive extracellular network (Liu et al., 2015; Wang et al., 2018). Consequently, mineral-mediated syntrophy is energetically more favorable than the usual syntrophic associations.

It has been proposed that Fe-minerals such as pyrite helped nucleate the membranes of the earliest cells (Wächtershäuser, 1988a; Russell et al., 1994). Many membrane bound proteins involved in electron transfer through the membranes of present day cells contain FeS centers 
(i.e. ferredoxins). It is therefore likely that some of the earliest FeS proteins might have played a role in electron transfer between cells.

It has been speculated that conductive-minerals also mediate the interaction between protocells with leaky cell walls present in the mineral-rich Archaean ocean (Lane \& Martin, 2012). Interactions between cells with different metabolisms are thought to be at the origin of eukaryogenesis, as such cells compartmentalized the functions within the eukaryotic cell (Moreira \& Lopez-Garcia, 1998; López-García \& Moreira, 1999; Martin \& Russell, 2003). In the present study, we investigated the conductive iron-mineral dependency of interspecies interactions between bacteria and methanogens from the sediments of the Fe-rich, stratified Lake La Cruz. Specifically, we were interested in whether reactive $\mathrm{Fe}$ minerals would support conductive-mineral mediated interspecies interactions. As the biogeochemical setting of the lake makes it a prime early analogue (Walter $e t$ al., 2014, Camacho et al., 2017), we also discuss mineral-mediated syntrophy as a relic of ancestral associations.

\section{MATERIAL AND METHODS}

\section{Sampling and incubations}

During an expedition at Lake La Cruz in central Spain (Fig. 1) in September 2014, we sampled the lake water and sediment. Lake La Cruz is a permanently stratified, meromictic, doline lake located in a karst region in the Iberian Mountain Range. The lake is circular with a diameter of $122 \mathrm{~m}$. At the time of sampling, the maximum depth was 20 $\mathrm{m}$ and the chemocline started at $\sim 12 \mathrm{~m}$ depth. Water samples were pumped from depths above,

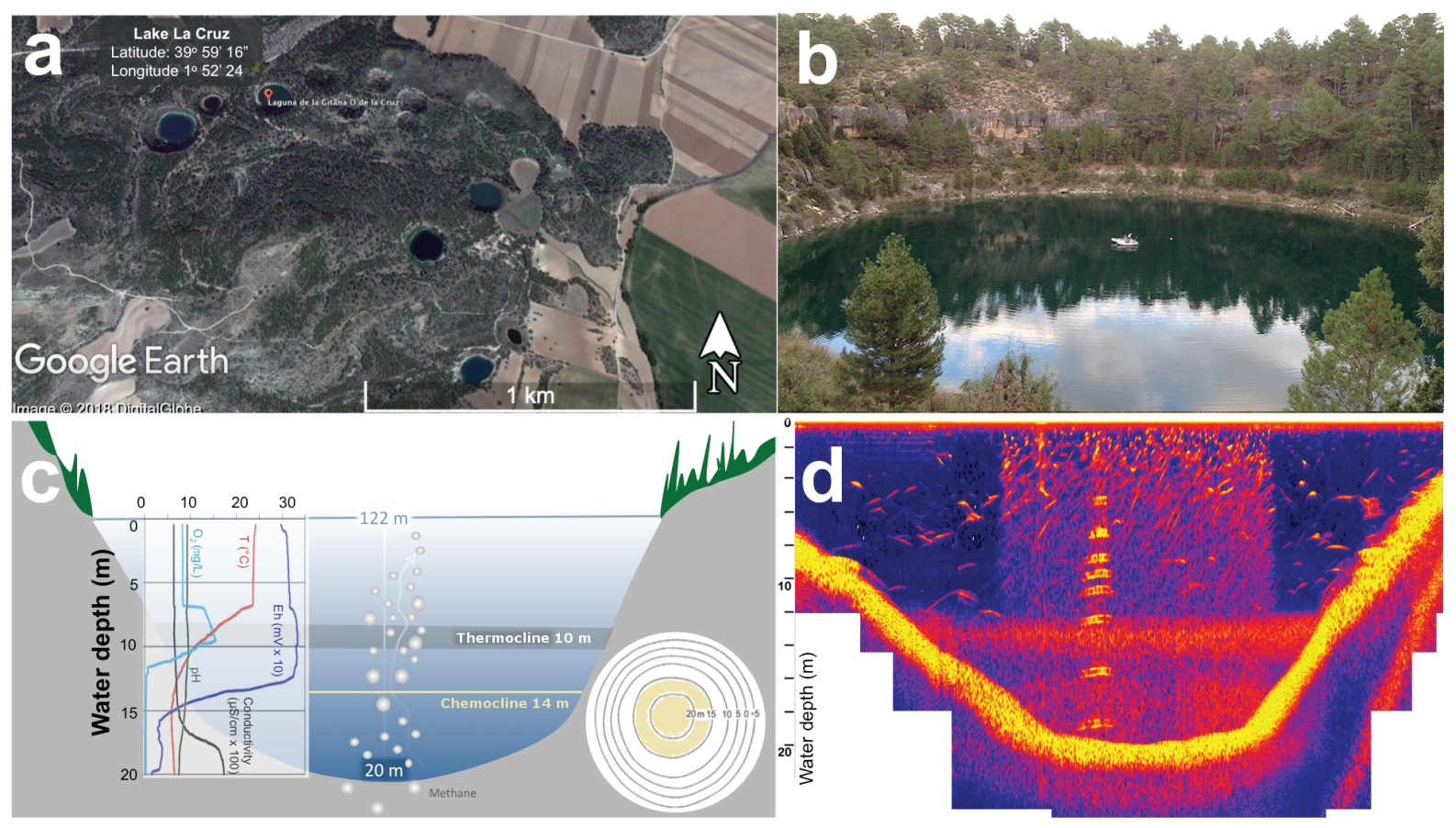

Figure 1. Lake La Cruz with its geophysical features. Map of the Cuenca lake area with geographical coordinates (a); and an image of the sampling site - lake La Cruz (b). Schematic representation of the lake (c) including a bathymetric map (c-round inset), and in situ physico-chemical characteristics of the water column (c-graphic inset: - conductivity $\mu \mathrm{S} / \mathrm{cm},-$ temperature ${ }^{\circ} \mathrm{C},-$ oxygen mg/L, $\mathrm{pH},-\mathrm{Eh} \mathrm{mV}$ ). An echogram indicating the chemocline from 12-14 m, with visible gas ebullition in the central area (d). La laguna de La Cruz con sus características geofisicas. Mapa de la zona de Cuenca con coordenadas geográficas del lago estudiado (a); y una imagen del lugar de muestreo - laguna de La Cruz (b). Representación esquemática del lago (c) que incluye un mapa batimétrico y las características físico-químicas in situ en la columna de agua: $\left(-\right.$ conductividad $\mu \mathrm{S} / \mathrm{cm},-$ temperatura ${ }^{\circ} \mathrm{C},-\mathrm{oxigeno} \mathrm{mg} / \mathrm{L},-\mathrm{pH}$, - Eh mV). El ecograma muestra la quimioclina situada a 12-14 m, con ebullición gaseosa visible en la zona central (d). 
within, and below the chemocline at the deepest part of the lake from a boat tethered from shore to shore of the lake. The pumping apparatus was designed to withdraw water samples without contact with the atmosphere, and both the apparatus and sampling protocol have previously been described in detail (Miracle et al., 1992; Posth et al., 2017). Samples were gathered and fixed directly on the boat and stored until analysis in the lab.

Three sediment cores were collected from the center and the deepest part of the lake (coordinates: $1^{\circ} 52^{\prime} 24^{\prime \prime}$ West; 39 $39^{\circ}$ ' 16" North, Fig 1) using a sediment corer (Kajak sediment core, KC Denmark). The cores $(50 \mathrm{~cm}$ length $\times 7 \mathrm{~cm}$ diameter) were sealed without air bubbles as they were pulled up from depth with rubber stoppers immediately inserted to avoid exposure to the atmosphere. Within 24 hours of sampling, the sediment was partitioned into depth intervals, and fixed for biogeochemical and molecular analyses inside an $\mathrm{N}_{2}$-filled inflatable glove bag, as described in detail below.

For downstream incubations, sediment from $0-15 \mathrm{~cm}$ depth was sampled and placed in Duran bottles secured with butyl-rubber stoppers, with a headspace of 2 bars $\mathrm{N}_{2}: \mathrm{CO}_{2}$ 80:20 mix. Samples were stored at $4{ }^{\circ} \mathrm{C}$ until later used for incubations.

Slurries were prepared in an $\mathrm{N}_{2}$-filled anaerobic chamber in the laboratory. For these slurries, we used $3 \mathrm{~mL}$ cut-off syringes to distribute 2.5 $\mathrm{mL}$ of sediment into $20 \mathrm{~mL}$ gas-tight vials filled with $7.5 \mathrm{~mL}$ of medium, either modified DSM 120 or DSM 334. Modified DSM 120 medium was prepared as described previously (Rotaru $e t$ al., 2014b), but with $0.6 \mathrm{~g} / \mathrm{L} \mathrm{NaCl}$. Three successive ten-fold dilutions of the sediment slurries led to essentially mud-free enrichments in which sediment particles could not be detected visually or by microscopy. Before inoculation, the complete medium, which lacked the substrate and (semi)conductive minerals, was dispensed anaerobically by syringe into sterile degassed vials with or without minerals prepared as below.

Two electrically conductive particle types (granular activated carbon and magnetite) were selected to be tested because they were previously confirmed to stimulate DIET in methanogenic co-cultures (Liu et al., 2012; Zheng et al., 2017).
Granular activated carbon (GAC, Sigma Aldrich) had a particle size between 180 and $300 \mu \mathrm{m}$ diameter and estimated conductivity of circa $1000 \mathrm{~S} / \mathrm{m}$ (Kastening et al., 1997), and magnetite (Sigma Aldrich) with particles less than $5 \mu \mathrm{M}$ diameter, and estimated electrical conductivity ranging between 0.1 and $1 \mathrm{~S} / \mathrm{m}$ (Rochelle \& Schwertmann, 2003; Blaney, 2012). Both materials have conductivities similar or higher than the pili that carry out extracellular electron transfer in Geobacter sulfurreducens (5 S/m (Adhikari et al., 2016)). We weighed $0.1 \mathrm{~g} / \mathrm{L}$ of each material, added to vials, overlaid with $200 \mu$ ultrapure water for wet sterilization, degassed for 3 minutes with $\mathrm{N}_{2}: \mathrm{CO}_{2}$ 80:20 mix, and autoclaved at 121 ${ }^{\circ} \mathrm{C}$ for $25 \mathrm{~min}$. Controls with non-conductive particles were setup with acid-washed glass beads (less than $105 \mu \mathrm{m}$ diameter) instead of conductive minerals. Substrates $(5 \mathrm{mM}$ glucose, $5 \mathrm{mM}$ sodium butyrate, $10 \mathrm{mM}$ sodium acetate, $10 \mathrm{mM}$ ethanol) were added to media from sterile anoxic $1 \mathrm{M}$ stocks using aseptic and anaerobic techniques. Controls without electron donors were carried out in order to identify whether the organics in the sediment served as substrates for methanogenesis. All incubations were carried out at room temperature $\left(20-23{ }^{\circ} \mathrm{C}\right)$ in triplicate, unless otherwise stated.

Gas samples were withdrawn, stored anaerobically and then analyzed for methane on a Thermo Scientific gas chromatograph (Rotaru et al., 2018). To test for short chain volatile fatty acids (SCVFA) we used high performance liquid chromatography (HPLC) as described elsewhere (Rotaru et al., 2018).

\section{Biogeochemistry}

For biogeochemical parameters, we took water column samples at different depths and sampled the sediment obtained via the gravity corer. Geochemical parameters of relevance to this work were methane, soluble ferrous iron, and particulate reactive iron mineral species. We will use the term reactive iron species to refer to oxalate, dithionite and $\mathrm{HCl}$ soluble iron oxides and sulfides (Poulton et al., 2004).

Water column methane was sampled from the pumping apparatus through chemically resistant 
tubing (VWRs ISO-VERSNIC ${ }^{\circledR}$ ) into $20 \mathrm{~mL}$ glass, GC vials (Supelco, Sigma-Aldrich). For each sampling depth, $5 \mathrm{~mL}$ samples in triplicate were added to GC vials pre-doped with $10 \mathrm{~mL} 2$ $\mathrm{N} \mathrm{NaOH}$ to retain $\mathrm{CO}_{2}$ in the liquid phase. The vials were sealed with butyl-viton rubber stoppers, and stored upside down in the dark at 4 ${ }^{\circ} \mathrm{C}$ until analysis.

Sediment methane concentrations were determined from sediment slices extracted every $2 \mathrm{~cm}$ in an anoxic glove bag filled with $\mathrm{N}_{2}$ gas.

Our measurements of available electron acceptors at the sediment boundary layer corroborated previous investigations during summer months at this lake (Miracle et al., 1992; Walter et al., 2014; Camacho et al., 2017) and showed a depletion of sulfate and $\mathrm{Fe}^{3+}\left(<10 \mu \mathrm{M}\right.$ sulfate, $\left.<1 \mu \mathrm{M} \mathrm{Fe}{ }^{3+}\right)$ and no detection of oxygen and nitrate. Thus sediments mainly relied on methanogenesis for decomposition of organic matter below the water-sediment boundary. For sedimentary methane determination, sliced sediment was filled into glass GC vials, to which $1 \mathrm{M}(2.5 \%) \mathrm{NaOH}$ was added in order to stop any additional microbial activity. The vials were capped with butyl-viton stoppers, crimped, and inverted until lab analysis. Sedimentary methane concentrations were determined on a Perkin Elmer GC, as previously described (Rotaru et al., 2018).

Porewater was analysed for reduced iron concentrations at $\sim 2 \mathrm{~cm}$ depth resolution after extraction using Rhizons (Rhizosphere; pore size $0.2 \mu \mathrm{m})$ inside a glove bag with an $\mathrm{N}_{2}$-atmosphere. Dissolved $\mathrm{Fe}^{2+}$ was determined immediately using the ferrozine assay (Lovley \& Phillips, 1987; Viollier et al., 2000).

To determine iron mineral speciation, sediment was subsampled at each $2 \mathrm{~cm}$-depth interval and stored at $-20{ }^{\circ} \mathrm{C}$. Reactive iron species (dithionite and $\mathrm{HCl}$ soluble iron species) were identified from freeze-dried samples stored at $-20{ }^{\circ} \mathrm{C}$ by applying a modified sequential iron extraction procedure (Poulton \& Canfield, 2005). In the first step, a room temperature $0.5 \mathrm{~N} \mathrm{HCl}$ extraction was applied to dissolve poorly crystalline iron oxides such as ferrihydrite, surface absorbed $\mathrm{Fe}^{2+}$, iron carbonate minerals such as siderite, and acid volatile iron monosulfides (Zegeye et al., 2012). Subsequently, a pH 4.8 sodium dithionite extraction was employed to dissolve crystalline ferric oxide minerals such as goethite and hematite, followed by an oxalate extraction to dissolve magnetite (Poulton \& Canfield, 2005). The total concentration of iron dissolved in each operationally defined extraction phase was determined by flame atomic absorption spectroscopy (AAS). For the $0.5 \mathrm{~N} \mathrm{HCl}$ extraction, dissolved $\mathrm{Fe}^{2+}$ was also measured immediately via the ferrozine assay (Lovley \& Phillips, 1987). Extraction of this $\mathrm{Fe}^{2+}$ from the total $\mathrm{Fe}$ determined for this extraction by AAS gave the $\mathrm{Fe}^{3+}$ concentration associated with poorly crystalline iron oxides such as ferrihydrite. Iron sulfide phases were determined via a two-step sequential extraction procedure (Canfield et al., 1986). Acid volatile sulfide minerals (FeS) were determined by extraction with hot $6 \mathrm{~N}$ $\mathrm{HCl}$ under $\mathrm{N}_{2}$, with the released sulfide trapped as $\mathrm{Ag}_{2} \mathrm{~S}$. Pyrite $\left(\mathrm{FeS}_{2}\right)$ was then determined after addition of chromous chloride, with the sulfide again trapped separately as $\mathrm{Ag}_{2} \mathrm{~S}$. After filtration, the concentrations of $\mathrm{Fe}$ in $\mathrm{FeS}$ and $\mathrm{FeS}_{2}$ were determined stoichiometrically. The concentration of $\mathrm{Fe}$ present as $\mathrm{FeS}$ was subtracted from the $\mathrm{Fe}^{2+}$ concentration determined by the $0.5 \mathrm{~N} \mathrm{HCl}$ extractions, to give surface reduced and carbonate-associated $\mathrm{Fe}^{2+}$. Replicate extractions gave a RSD of $<5 \%$ for all phases.

\section{Scanning electron microscopy}

Samples from the water column were preserved in $4 \%$ formalin, filtered on Nucleopore carbonate filters, with a pore size of $0.2 \mu \mathrm{m}$, and dehydrated in 20 min. steps with ethyl alcohol (30\%, $50 \%, 70$ $\%, 90 \%$ and two times $100 \%$ ). Then the samples were critical point dried prior to palladium/gold sputter coating and visualization on a Hitachi S-4800 FE scanning electron microscope ran at an electron beam acceleration voltage of $20 \mathrm{kV}$.

\section{Molecular analyses}

For molecular analyses we sampled $2 \mathrm{~mL}$ of sediment at $2 \mathrm{~cm}$ depth resolution using cut-off syringes inside a $\mathrm{N}_{2}$-filled glove bag. Sediment was pooled together every $4 \mathrm{~cm}$ and fixed with MoBio RNAlater 1:1 v/v (Rotaru et al., 2018). 
Prior to DNA extractions, most of the RNAlater was removed by centrifugation. For DNA extraction we used the top $16 \mathrm{~cm}$ of sediment from triplicate cores. Extractions were carried independently for each core with the MoBio RNA Soil kit coupled to the MoBio complementary DNA Soil kit, following the manufacturer's protocol. DNA was quantified using a Nano Drop prior to downstream applications. The DNA extracted from each core was amplified with the following primer pair S-D-Arch-0519-a-S-15/ S-D-Bact-0785-b-A-18, which according to Klindworth et al. (2013), was the best for MiSeq amplicon sequencing, targeting more than $89 \%$ of Bacteria and more than $88 \%$ of Archaea. PCR amplification and indexing (using Nextera XT index kit, Illumina) of the PCR products for the triplicate samples was conducted following the Illumina 16S rRNA gene amplicon sequencing protocol (Illumina, USA). The DNA samples were then sequenced using $\times 300$ PE MiSeq sequencing approach at Macrogen (www.macrogen.com), using Illumina's protocol. The sequences generated circa 1 million reads for each core, which were imported into CD-HIT-OTU to remove noisy data and clustered into OTUs, using a $97 \%$ species
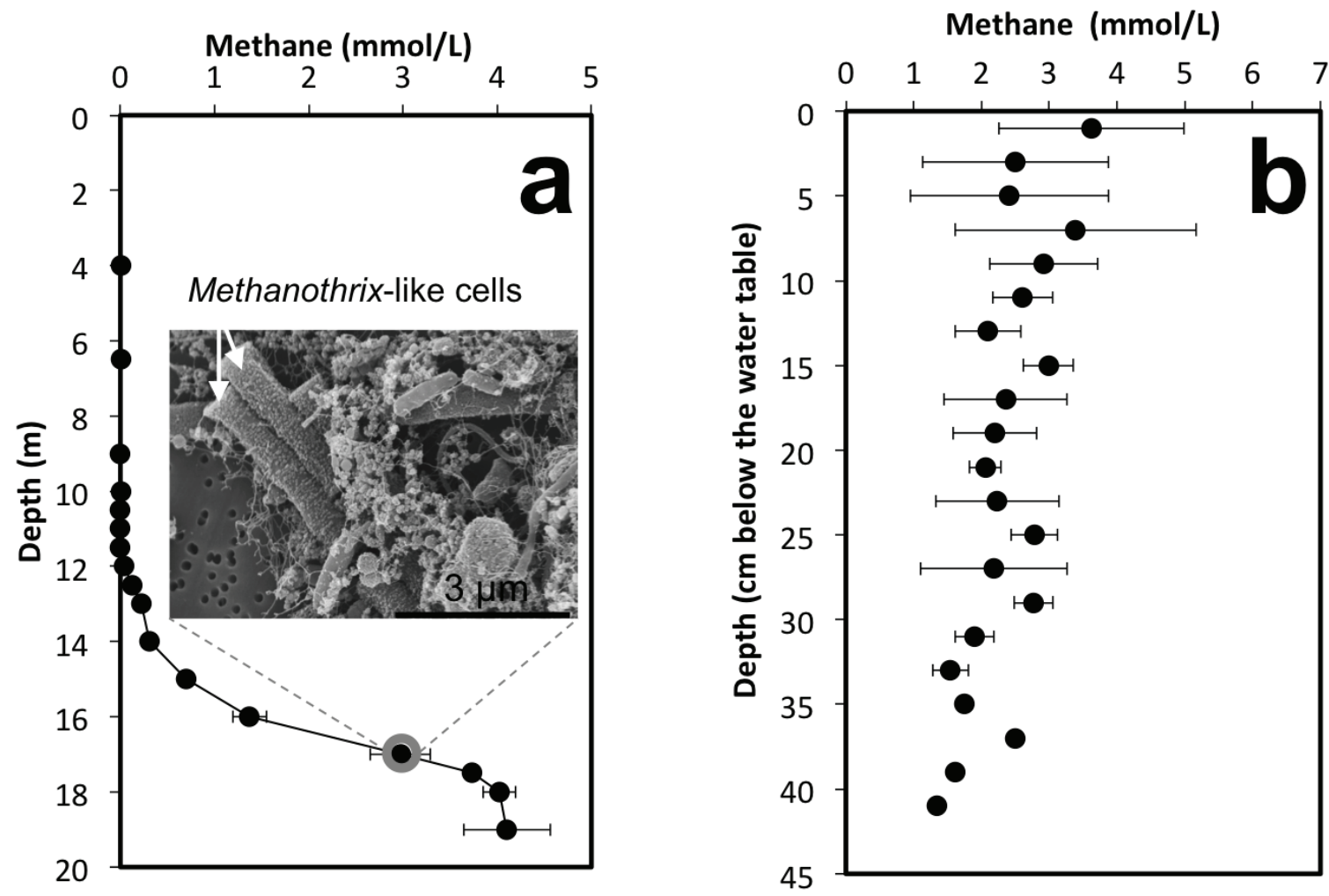

Figure 2. Methane profiling through the water column and sediment of lake La Cruz. (a) In the water column of Lake La Cruz, the highest methane concentrations were below 17-m depth where Methanothrix-like cells (inset) could be observed by scanning electron microscopy. (b) Sediment cores showed very high methane concentrations especially in the top 15-cm, indicating that methane has also sedimentary origin. The water column values as average \pm standard error values are for triplicate samples taken at each specific water column depth; while values for sediments are from triplicate cores sampled every 2-cm. Perfiles de metano en la columna de agua y en el perfil de los sedimentos de la laguna de La Cruz. (a) En la columna de agua de la laguna de La Cruz, las concentraciones más altas de metano se encontraban por debajo de los $17 \mathrm{~m}$ de profundidad, donde células similares a Methanothrix (recuadro) se podian observar mediante microscopía electrónica de barrido. b) Los testigos de sedimento mostraron concentraciones muy elevadas de metano, especialmente en los $15 \mathrm{~cm}$ superiores, lo que indica que el metano también tiene su origen en el sedimento. Los valores en la columna de agua son la media \pm el error estándar de muestras triplicadas tomadas a cada profundidad especifica en la columna de agua; mientras que los valores en los sedimentos son la media de testigos triplicados muestreados cada $2 \mathrm{~cm}$. 
cutoff. For taxonomy and diversity analyses, clean and clustered OTUs were analyzed using QIIME (Caporaso et al., 2010), against the Ribosomal Database Project database version 11. Alpha rarefaction analyses showed sufficient coverage of the diversity in all three sediment cores.

DNA extractions from mud-free incubations were performed using the MasterPure DNA purification kit as previously described (Rotaru et al., 2014b). Amplification of bacterial (27F, 5'-AGAGTTTGATCMTGGCTCAG and 1492R, 5'-TACCTTGTTACGACTT) and archaeal (344F - 5'-ACGGGGYGCAGCAGGCGCGA -3' and 1059R - 5'- GCCATGCACCWCCTCT-3') 16S rDNA sequences, library preparation, and $16 \mathrm{~S}$ rRNA gene sequencing, was performed as previously described (Rotaru et al., 2018). Maximum likelihood phylogenetic trees were constructed using Geneious (Kearse et al., 2012). Sequence files can be found at NCBI under Bioproject ID: PRJNA510210.

\section{RESULTS AND DISCUSSION}

Our hypothesis was that the iron-rich Lake La Cruz would be a breeding ground for conductive, mineral-based syntrophy (Rotaru et al., 2018). We discovered that microorganisms enriched from Lake La Cruz carried out syntrophic degradation strictly dependent on conductive mineral additions and were unable to carry unaided DIET associations.

\section{Geochemistry}

We expected to find a niche for DIET/conductive-particle mediated IET in this Fe-rich methanogenic lake resembling the ocean in the Precambrian. La Cruz sediments displayed high methane concentrations in the top $15 \mathrm{~cm}$, along with a significant proportion of reactive iron species $\sim 70 \%$ of the total Fe content) (Thompson 2018), which is very high relative to normal non-ferruginous aquatic environments (Poulton \& Raiswell, 2002). During this sampling campaign, the sediments were overlain by $\sim 10 \mathrm{~m}$ of anoxic water (Fig. 1). During summer months, the lake is known to persistently have a $4-5 \mathrm{~m}$ monimolimnion zone above the sediment, which is rich in $\mathrm{Fe}^{2+}$ (Vicente \& Miracle,
1988). In our study we also noticed strong methane super-saturation near the bottom, where the methane concentration reached $4 \mathrm{mM}$, similar to concentrations in the surface sediment (Fig. 2). Gas ebullition was observed during sampling from the deep water table. Oftentimes, gas bubbles mainly consisting of methane and carbon dioxide (Camacho et al., 2017), percolated through the surface of the lake from the middle, as documented by an ecogram of the lake (Fig. 1d). Previous studies suggest that the sediment is the source of water-column methane (Oswald et al., 2016). Indeed we observed that sediment methane concentrations were highest in the top centimeters of the sediment (Fig. 2). Methane concentrations were also high in the water column (17-20 m), indicating methanogenesis occured in the bottom waters as well as the top layers of the sediment (Fig. 2).

As documented previously (Oswald et al., 2016; Camacho et al., 2017), dissolved $\mathrm{Fe}^{2+}$ did build up below the chemocline to reach concentrations of $\sim 250 \mu \mathrm{M}$ above the sediment-water interface. In the sediment, dissolved $\mathrm{Fe}^{2+}$ concentrations continued to increase (Thompsen, 2018), reaching a peak of $>1000 \mu \mathrm{M}$ at a depth of $\sim 22$ $\mathrm{cm}$. These high dissolved $\mathrm{Fe}^{2+}$ concentrations in the water column and sediment porewaters are similar to those found in other iron-rich lakes (Vicente \& Miracle, 1988; Bura-Nakic et al., 2009; Crowe et al., 2011; Nordi et al., 2013) . The La Cruz sediments were high in TOC (average $=$ $6.68 \pm 2.0 \mathrm{wt} \%$ ), and carbonate minerals (average $=9.46 \pm 1.3 \mathrm{wt} \%$ inorganic $\mathrm{C}$ ), which diluted the total Fe-content to $1.06 \pm 0.18 \mathrm{wt} \%$ on average (Thompson, 2018). This is considerably lower than the average global total $\mathrm{Fe}$ content of riverine particulates supplied to oceans and lakes (4.49 wt \%; Poulton \& Raiswell, 2002). Proportionally, however 'reactive' Fe phases (non-sulphidized $\mathrm{Fe}^{2+}$, Fe-oxides, Fe-sulfides) were abundant (70 $\pm 8 \%$; Thompson, 2018) relative to the total Fe content of the sediment, of which only $18 \pm 5 \%$ was sulfur bound (pyrite, other Fe-S minerals). Nevertheless, magnetite $\mathrm{Fe}$ accounted for less than $0.1 \%$ of the total Fe-content in this sediment, while other Fe oxide minerals accounted for $\sim 10 \%$ of total $\mathrm{Fe}$ on average. Thus, non-sulphidized particulate $\mathrm{Fe}(\mathrm{II})$ was the dominant reactive Fe pool ( $\sim 60 \%$ on average). 


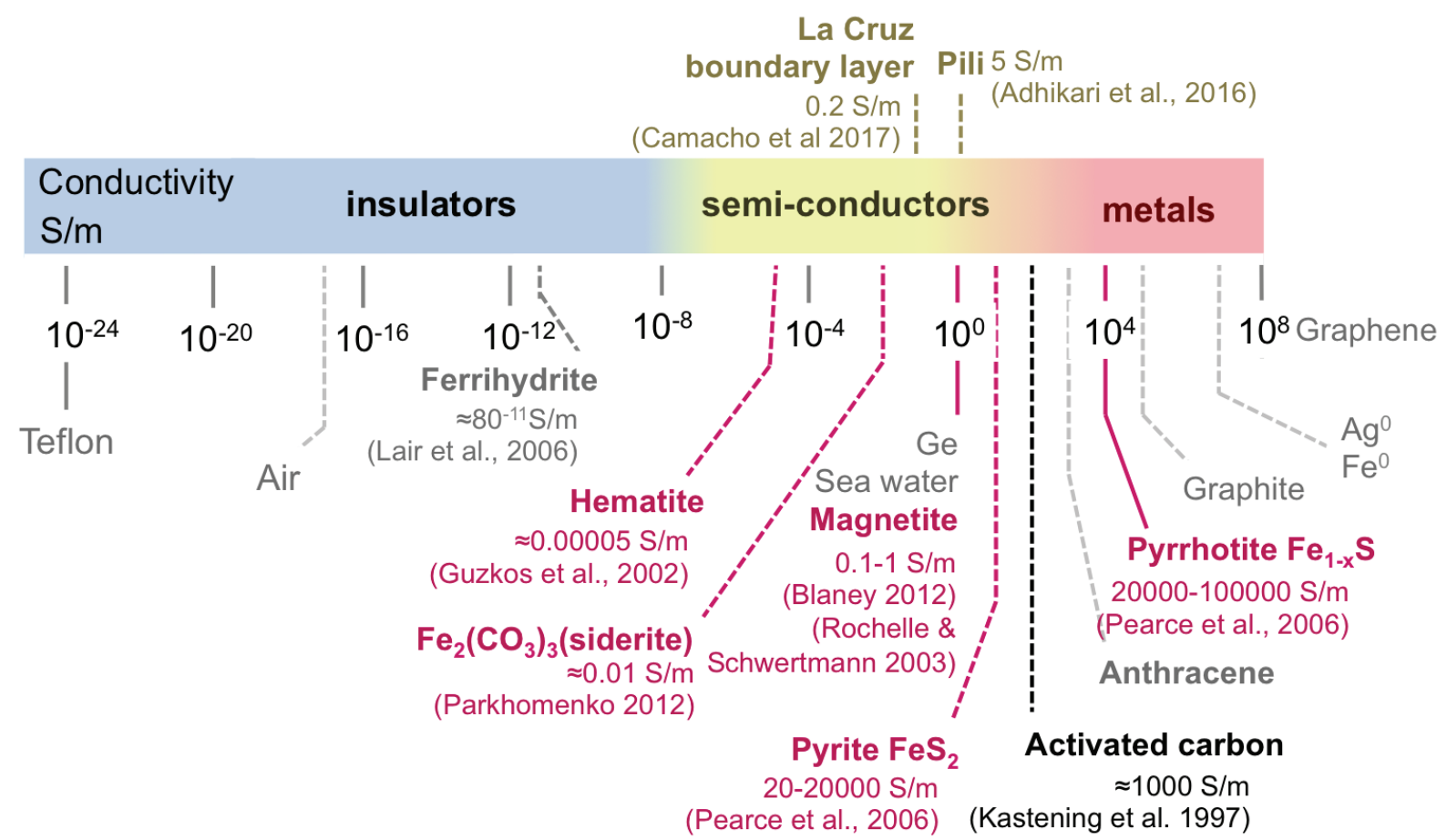

Figure 3. Conductivities of various Fe-oxides and Fe-sulfides, compared to that of the e-pili and the conductivities observed for different carbon particles including activated carbon used in this study. We have also listed the conductivity measured in lake La Cruz at the sediment-water boundary layer. (Adhikari et al., 2016; Blaney, 2012; Camacho et al., 2017; Guskos et al., 2002; Kastening et al., 1997; Lair et al., 2006; Parkhomenko, 1990; Pearce et al., 2006; Rochelle and Schwertmann, 2003). Conductividades de varios óxidos y sulfuros de Fe, comparadas con las de los pelos bacterianos conductores (e-pili) y las conductividades observadas para diferentes partículas de carbón incluyendo el carbón activado utilizado en este estudio. También hemos enumerado la conductividad medida en la laguna de La Cruz en la interfase sedimento-agua. (Adhikari et al., 2016; Blaney, 2012; Camacho et al., 2017; Guskos et al., 2002; Kastening et al., 1997; Lair et al., 2006; Parkhomenko, 1990; Pearce et al., 2006; Rochelle \& Schwertmann, 2003).

Some of the iron minerals (Fe-sulfides and Fe-oxides) found in the sediments of lake La Cruz are electrically conductive (Fig. 3), of which magnetite and iron sulfides have been documented to facilitate mineral mediated syntrophy (Liu et al., 2012, 2015; Zheng et al., 2017; Rotaru et al., 2018; Kato \& Igarashi, 2018). Fe-sulfides, like pyrite have been also shown to aid long-range extracellular electron transfer from cells (Kondo et al., 2015) or enzymes (Mahadevan \& Fernando, 2018) to electrodes. Moreover La Cruz sediments also contain coal particles (Romero-Viana et al., 2011), which are conductive (Fig. 3). Indeed it has been documented that conductive carbon materials (i.e. granular activated carbon) facilitated mineral mediated syntrophy as effectively as conductive Fe-minerals (Liu et al., 2012; Rotaru et al., 2018).

\section{In situ bacterial diversity - with focus on described electrogens}

We therefore anticipated that electrically conductive particles inherent to $\mathrm{La}$ Cruz sediments would facilitate mineral mediated interactions between electrogens and electrotrophic methanogens. Indeed, our data demonstrate that the community harbors organisms affiliated to groups of electrogens including Geobacter (Fig. 4), and to DIET-methanogens including Methanothrix (Fig. 4). Geobacter and Methanothrix have previously been shown to carry out DIET in laboratory co-cultures (Rotaru et al., 2014a), and have been found to co-exist in several man-made environments, such as rice paddies (Holmes et al., 2017) and anaerobic digesters (Morita et al., 2011; Rotaru et al., 2014a). Our data showed that bacte- 
ria affiliated to known electrogens/iron-reducers like Geobacter $(0.6 \%$ of all Bacteria), Thiobacillus ( $0.2 \%$ of all Bacteria), Desulfobacterium ( 0.4 $\%$ of all Bacteria), and Anaerolinea $(0.1 \%$ of all Bacteria) co-existed with Methanothrix in Lake La Cruz sediments (Fig. 4). Together, all of these putative electrogens/iron reducers, summed up to circa $1 \%$ of all Bacteria. Previously, members of these four genera, Geobacter, Thiobacillus, Desulfobacterium, Anaerolinea, have been shown to be capable of extracellular electron transfer to and/or from electrodes or metallic iron (Nakasono et al., 1997; Dinh et al., 2004; Gregory et al., 2004; Kawaichi et al., 2018; Pous et al., 2014; Rotaru et al., 2015), as well as iron-minerals (Bosch et al., 2012; Kawaichi et al., 2013; Lovley et al., 1993; Rotaru et al., 2015). The first two, Geobacter and Thiobacillus can also interact by DIET with other cells (Summers et al., 2010; Kato et al., 2012; Rotaru et al., 2014b, 2014a;), and this interaction has been shown to be expedited in the presence of conductive particles (Kato et al., 2012; Liu et al., 2012; Chen et al., 2014; Liu et al., 2015; Rotaru et al., 2014b; Zheng et al., 2017). It is therefore possible that all of these electrogenic species compete for the electron uptake of electrotrophic methanogens.

However, one of the most abundant genera in these sediments was Smithella $(2.6 \%$ of all bacteria), which has been assumed to be electroactive and carry DIET interactions with Methanothrix in an alkane-degrading consortium (Embree et al., 2014). Therefore, Smithella may establish a DIET-association with Methanothrix from Lake La Cruz sediments (see Archaea community below). Members of Verrucomicrobia
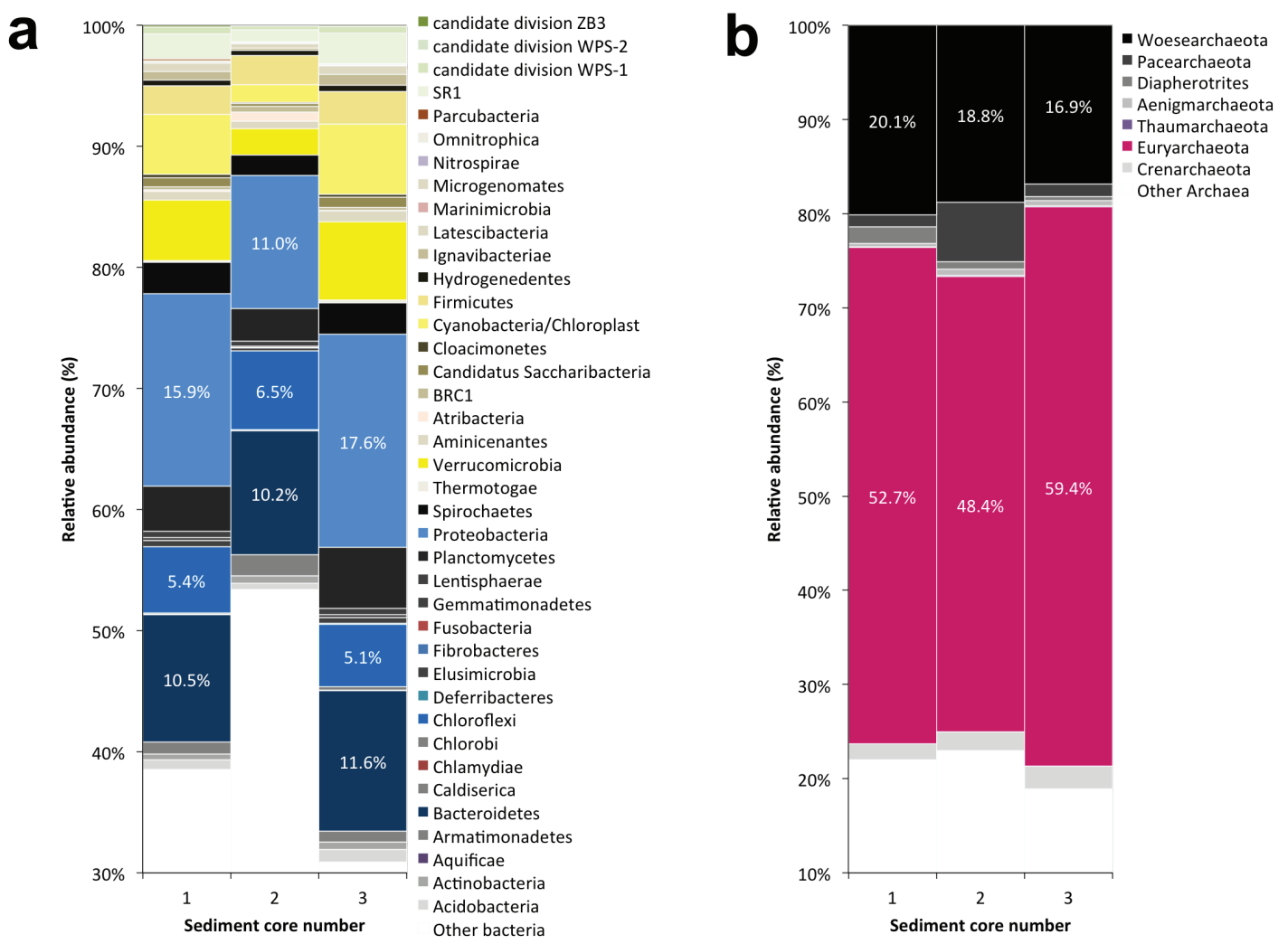

Figure 4. Relative phylum-level composition of (a) Bacteria and (b) Archaea harboring the top 16-cm of three sediment cores from lake La Cruz, as determined by $16 \mathrm{~S}$ rRNA gene amplicon sequencing. Composición relativa a nivel de filum de (a) Bacterias y (b) Arqueas albergadas en los $16 \mathrm{~cm}$ superiores de tres testigos sedimentarios de la laguna de La Cruz, según lo determinado por la secuencia del amplicón del gen 16S rRNA. 
were also very well represented (ca. $4.6 \%$ of all bacteria) similar to what has been observed for $90 \%$ of several lake sediments (He et al., 2017). Verrucomicrobia were recently proposed to carry extracellular electron transfer due to their genetic make-up, which comprises the appropriate porin systems and membrane-associated c-type cytochromes (He et al., 2017). It is also possible that Verrucomicrobia play a role in mineral mediated interspecies interactions. Nevertheless, Verrucomicrobia have never been shown to have the ability to interact syntrophically or to carry out extracellular electron transfer in laboratory cultures, and thus this predicted physiology requires further investigation. Some of the most abundant phyla were Bacteroidetes (10.8\% of the bacteria), and Firmicutes $(2.5 \%$ of all bacteria) (Fig. 4).

\section{In situ archaeal diversity}

Euryarchaeaota accounted for more than half of the Archaea represented through amplicon sequencing (Fig. 4). Here, we show that in the sediments of Lake La Cruz, Methanothrix co-existed with electrogens (Geobacter, Thiobacillus, Desulfobacterium, and Smithella). Besides the acetoclastic/DIET-associated Methanothrix (3.7 $\%$ of all archaea), we identified canonical hydrogenotrophic-methanogens belonging to Methanoregula $(2.5 \%$ of all archaea), and very low numbers of Methanobacterium ( $0.2 \%$ of all Archaea). The most abundant Archaea were the deepbranching Methanomassilicoccus (40.6\% of all archaea). The role of Methanomassillicoccus in sedimentary methanogenesis is not well understood since their only cultivated species-representative, M. luminyiensis, is a human-gut isolate strictly capable of $\mathrm{H}_{2}$-dependent methylotrophic methanogenesis, but incapable of $\mathrm{CO}_{2}$-reductive methanogenesis or acetoclastic methanogenesis (Dridi et al., 2012a). Besides their documented presence in the gut of humans (Dridi et al., 2012b), other animals (i.e. Salgado-Flores et al., 2016) or insects (Paul et al., 2012), Methanomassilicoccus sp. have also been found in anaerobic digesters (e.g. Chojnacka et al., 2015), hydrothermal springs (e.g. Coman et al., 2013), subsurface aquifers and soils (e.g. Kadnikov et al., 2017), and aquatic sediments (e.g. Rotaru et al., 2018) to name a few. Methanomassiliicoccus was also one of the most abundant genera of methanogens, not only in the iron-rich sediments of Lake La Cruz, but also in Baltic Sea sediments that are potential niches for conductive particle-mediated syntrophy (Rotaru et al., 2018). It is possible that Methanomassilicoccus is involved in electroactive interactions via minerals, especially taking into account that this group was recently associated with electroactive communities abundant on electrodes from bioelectrochemical systems set up with inoculums from soils (Ahn et al., 2014) and anaerobic digester sludge (Park et al., 2018).

Among the methanogens detected in La Cruz sediments, only species of Methanothrix have been previously shown to establish DIET-associations with Geobacter species (Morita et al., 2011; Rotaru et al., 2014a; Wang et al., 2016; Holmes et al., 2017). Methanothrix was earlier suggested to carry out DIET with Smithella (Embree et al., 2014), but the latter has never been shown to be capable of mineral-mediated or direct electron transfer. In a previous study, we have shown that a Methanothrix-species from the Baltic did not establish a mineral-mediated interaction with Baltic-Geobacter, but were instead competitively excluded by a Methanosarcina-Geobacter consortium, which carried a mineral-mediated syntrophic association (Rotaru et al., 2018). However, although Methanosarcina is a very effective DIET partner (Rotaru et al., 2014b, 2015) and mineral-syntrophy partner ( Liu et al., 2012; Chen et al., 2014; Wang et al., 2018; Rotaru et al., 2018) they were poorly represented in La Cruz sediments (Fig. 4).

\section{High methanogenic activity could only be maintained by conductive particles}

To determine the effect of conductive particles on the Lake La Cruz methanogenic community, we compared incubations with or without additional conductive particles. These incubations showed that the methanogenic community was strictly dependent on the addition of conductive particles and independent of the type of substrate, conductive particle, or freshwater medium tested (Fig. 5). Incubations with conductive particles showed 2 to 
4 fold increases in methanogenic rates $(0.2-0.7$ $\mathrm{mM} /$ day, depending on substrate) over incubations with non-conductive glass beads or without particle-amendment $(0.09$ to $0.18 \mathrm{mM} /$ day, depending on the substrate). Moreover, high methanogenic activity was maintained in subsequent incubations only if conductive particles were added (Fig. 5). Cultures without conductive particles could not sustain methanogenesis for more than one subsequent transfer. This indicates a strict dependency of the enriched methanogenic community on conductive particles.
We observed that all tested substrates were transiently converted to acetate, which was converted quickly to methane in the presence of conductive particles, whereas acetate accumulated in the absence of conductive particles (Fig. 5). This is likely due to higher rates of acetate oxidation prompted by the addition of conductive particles, similar to previous observations of Bothnian Bay sediments where syntrophic acetate oxidation (SAO) relied on conductive minerals (Rotaru et al., 2018).

We determined which organisms were
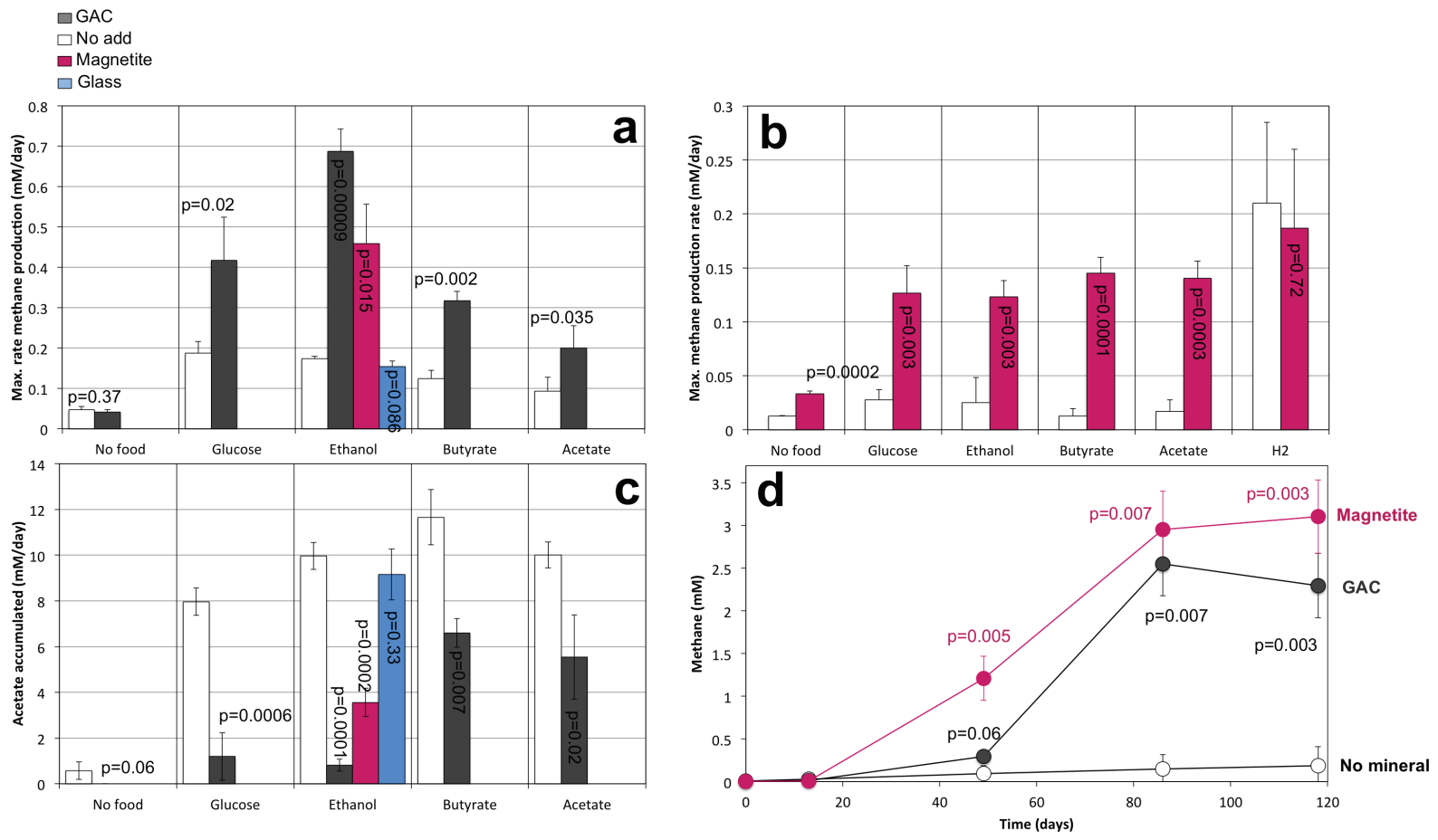

Figure 5. Methanogenesis on different substrates in incubations from lake La Cruz samples. Methane production in initial slurry incubations provided with different substrates was stimulated by conductive particles (GAC or magnetite) independent of the media used (a) modified DSMZ 120 or (b) DSMZ 334. (c) Acetate accumulated in incubations without conductive particles, but was significantly lower at the addition of conductive particles. (d) For example, a third transfer free of sediment showed that methanogenesis and acetate consumption were strictly dependent of the presence of conductive particles (colored symbols), and ceased if conductive particles were not added consistently for subsequent transfers (white symbols). Values represent average \pm standard deviation and are based on triplicate incubations, with the exception of the incubation with acetate plus GAC, where we had duplicates. Metanogénesis con diferentes sustratos en incubaciones con muestras del lago La Cruz. La producción de metano en las incubaciones iniciales de lodos provistos con diferentes sustratos fue estimulada por particulas conductivas (GAC o magnetita) independientemente del medio utilizado (a) DSMZ 120 modificado o (b) DSMZ 334. (c) Acetato acumulado en incubaciones sin partículas conductivas, que fue significativamente menor tras la adición de partículas conductivas. (d) Por ejemplo, una tercera transferencia libre de sedimento mostró que la metanogénesis y el consumo de acetato dependian estrictamente de la presencia de partículas conductivas (símbolos de color), y cesaban si las partículas conductivas no se añadian consistentemente para las transferencias subsiguientes (símbolos blancos). Los valores representan la media y la desviación estándar y están basados en incubaciones triplicadas, excepto la incubación con acetato incorporado de GAC, que fueron por duplicado. 

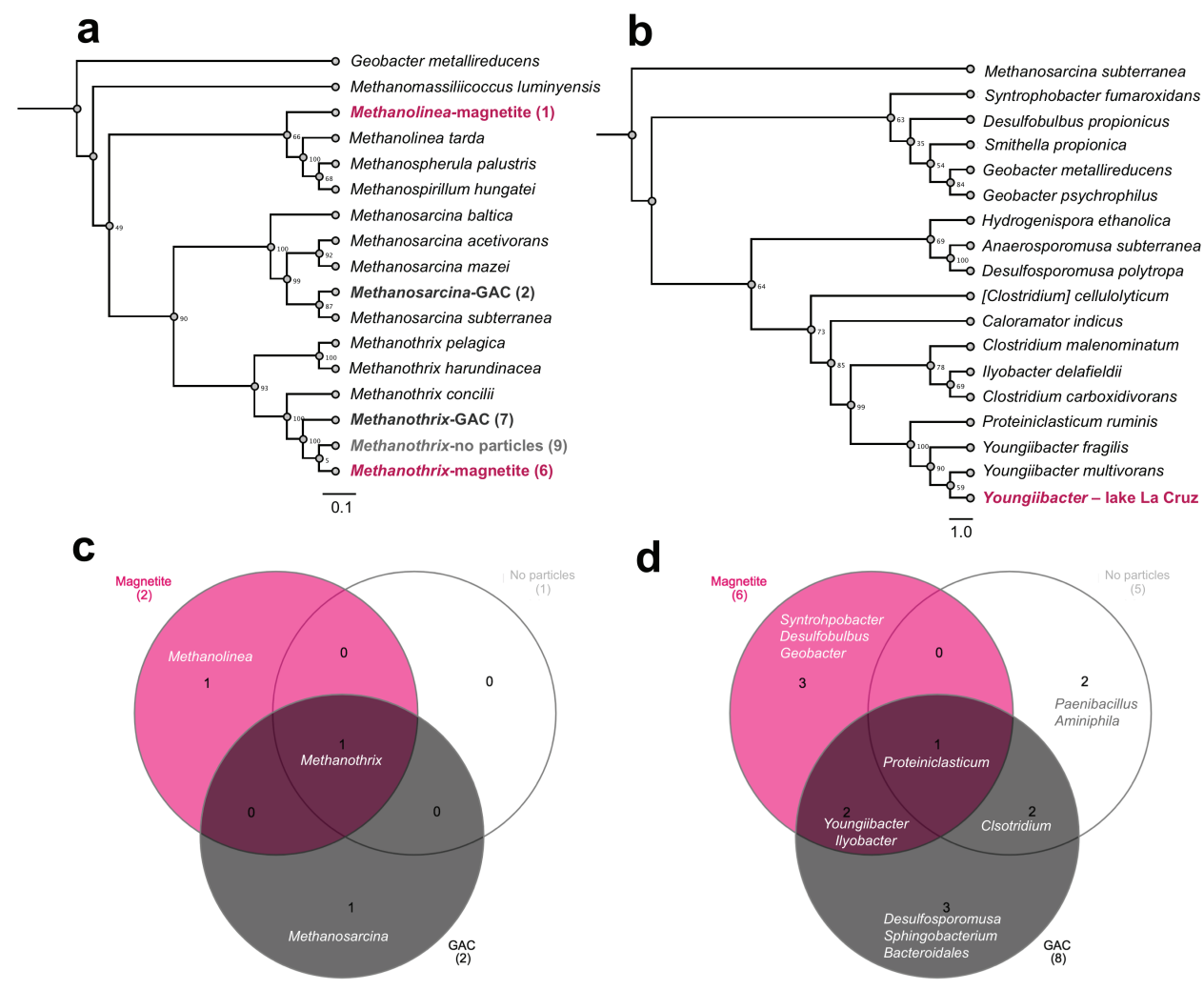

Figure 6. Maximum likelihood phylogenetic trees $(\mathrm{a}, \mathrm{b})$ and Venn diagrams with the relative distribution of 16S rRNA-gene sequences for Archaea (a, c) and Bacteria (b, d) in La Cruz incubations with or without conductive particles. Archaeal (a) and Bacterial (b) $16 \mathrm{~S}$ rRNA genes were retrieved from third mud-free transfer of acetate-incubations with magnetite (pink), and GAC (black-bold) or from a first mud-free transfer without conductive particles (light gray-white). (c) The only Archaeal 16S phylotype encountered in all incubations independent of treatment was Methanothrix-related. (d) The most abundant Bacterial phylotype encountered only in conductive particle-amended incubations was Youngiibacter-related. Árboles filogenéticos de máxima verosimilitud (a, b) y diagramas de Venn con la distribución relativa de las secuencias del gen $16 S$ rRNA para Archaea $(a, c)$ y Bacteria $(b, d)$ en incubaciones de muestras de La Cruz con o sin partículas conductivas. Los genes Archaeal (a) y Bacterial (b) $16 S$ rRNA se recuperaron de la tercera transferencia sin sedimento en incubaciones con acetato y magnetita (rosa) y GAC (negro fuerte) o de una primera transferencia sin sedimento y sin partículas conductoras (gris claro-blanco). (c) El único filotipo de $16 S$ de Archaeas encontrado en todas las incubaciones, independiente del tratamiento, estaba relacionado con Methanothrix. (d) El filotipo bacteriano más abundante encontrado solo en incubaciones complementadas con adición de partículas conductivas fue del tipo relacionado con Youngiibacter.

enriched on acetate with or without conductive particles. For this we compared the acetate fed communities exposed to two types of conductive particles (GAC and magnetite) to a community exposed to no conductive particles. We determined that Youngiibacter and Methanothrix methanogens dominated the enrichments amended with both types of conductive particle (Fig. 6). On the other hand, in controls without conductive particles, after only one single transfer Youngiibacter could not be detected. In the absence of conductive particles methane production only occurred slowly for one transfer and in this case Methanothrix co-existed with Clostridium (Fig. 6).

Youngiibacter was only found in enrichments with conductive particles and its presence could be associated with rapid acetate consumption coupled to methane production (Fig 5). We therefore anticipate that Youngiibacter plays a role in conductive-particle mediated syntrophy. Nevertheless, until now little is known about this group of Firmicutes, and only recently two species of Youngiibacter have been described (Lawson et al., 2014; Tanaka et al., 1991), of which one is 
associated with fermentation of organics on coal surfaces during coal conversion to natural gas (Lawson et al., 2014). Coal, similar to activated carbon, is electrically conductive (Duba, 1977). Moreover, Methanothrix have been also found associated with coal conversion to natural gas (Beckmann et al., 2011; Lawson et al., 2014). It is therefore possible that Youngiibacter and Methanothrix play a role in conductive particle-mediated syntrophy in coal beds, and as well in Lake La Cruz sediments. However, a syntrophic association between Youngiibacter and Methanothrix has not been described before. We suggest that Youngiibacter released electrons from substrate/acetate oxidation onto conductive minerals that are then used as a source of electrons for Methanothrix in order to reduce $\mathrm{CO}_{2}$ to methane. It is possible that Youngiibacter releases electrons extracellularly using a similar mechanism to that described for Geobacter namely a network of outer membrane $c$-type cytochromes (OMC) and pili (Shrestha et al., 2013). During DIET, OMCs were not as necessary for a donor Geobacter strain to carry substrate oxidation coupled with extracellular electron transfer (EET) and respiration, since OMCs could be completely replaced by the conductive iron oxide, magnetite (Liu et al.,
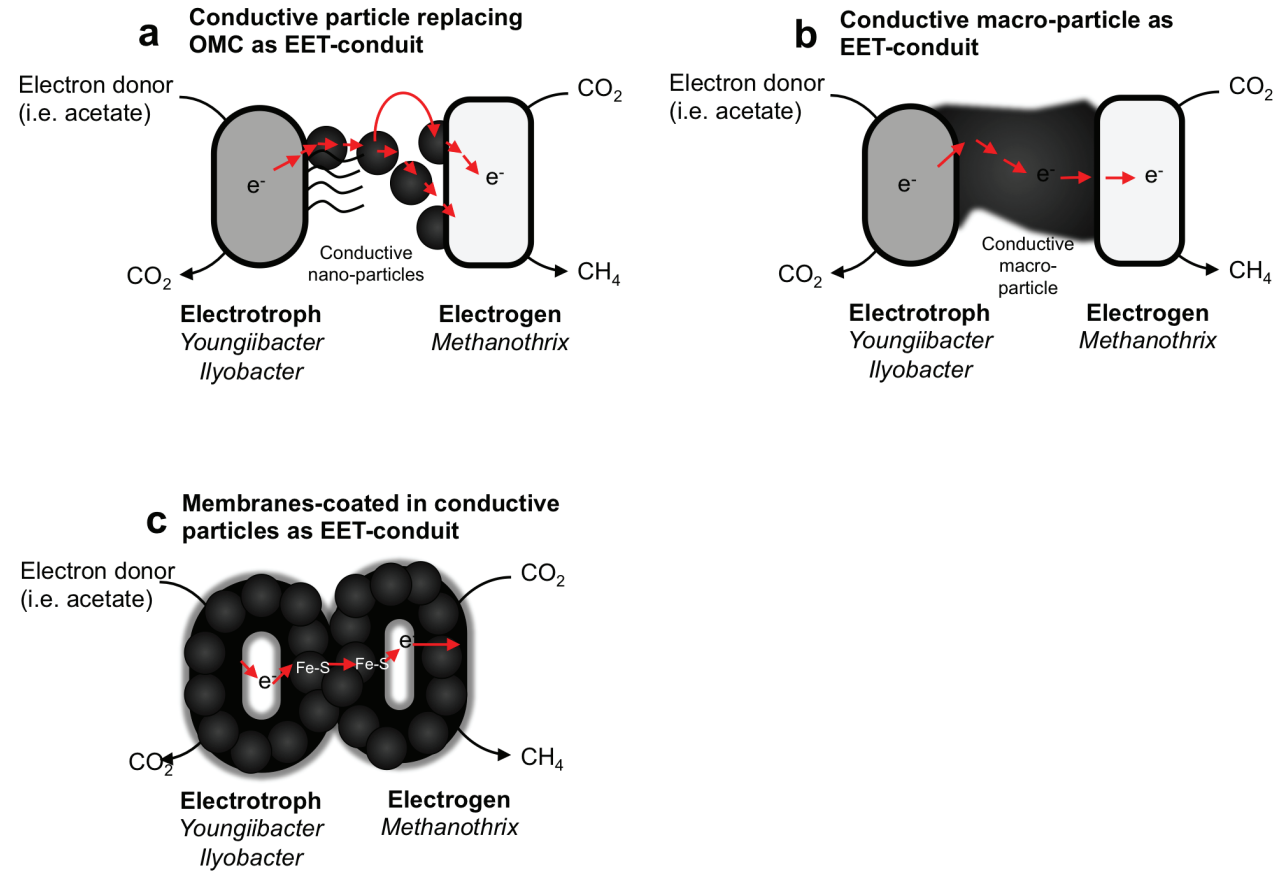

Figure 7. Proposed model interspecies interactions in La Cruz sediments facilitated by conductive particles. (a) Syntrophy mediated by a conductive nano-particles replacing outer membrane cytochromes (OMCs). Nevertheless, pili involved in EET are still available. (b) Syntrophy mediated by a conductive macro-particle (e.g. GAC), which plays the role of both and electron plug and outlet. (c) Syntrophy mediated by a conductive-mineral coat padding the cell surface. In lake La Cruz, conductive minerals could for example result from the precipitation of $\mathrm{Fe}^{2+}$ as $\mathrm{Fe}-\mathrm{S} /$ thiol-. Cell surfaces encrusted with a Fe-S coat might endorse the electron-transfer between the two distinct metabolic entities even in the absence of a typical EET/DIET conduit. Modelo de interacciones interespecies propuesto para los sedimentos de La Cruz facilitados mediante partículas conductivas. (a) Sintrofia mediada por nanopartículas conductivas que reemplazan a los citocromos de membrana externa (OMC). Sin embargo, los pili involucrados en EET todavía están disponibles. (b) Sintrofia mediada por una macropartícula conductiva (es decir, GAC), que desempeña el papel de ambos, la conexión y la fuente de electrones. (c) Sintrofia mediada por una envoltura mineral conductiva que rellena la superficie célular. En el lago La Cruz, los minerales conductivos podrían, por ejemplo, resultar de la precipitación de Fe ${ }^{2+}$ como Fe-S/tiolatos- en el espacio periplásmico de las células. Las superficies celulares incrustadas con una envoltura de sulfuros metálicos como Fe-S podrían avalar la transferencia de electrones entre las dos entidades metabólicas distintas, incluso en ausencia de un típico conducto EET / DIET. 
2015). Instead, when it plays the role of electron donor Geobacter seems to necessitate e-pili for long range electron transfer to partner cells, as exemplified in a recent study (Ueki et al., 2018). In agreement with previous observations in Geobacter, Youngiibacter might employ type IV pili for EET to partner Methanothrix. Youngiibacter's type IV pili gene sequence (T472_0202395) differs greatly from that of Geobacter in length (238 aminoacids longer than its correspondent in $G$. metallireducens) and sequence identity (only a stretch of 16 aminoacids showed $50 \%$ identity). Nevertheless, this prepilin-gene encodes for a protein with high content of aromatic aminoacids $(10.3 \%)$ which could give this organism an advantage to carry EET (Walker et al., 2018). It is possible that conductive particles ornate the pili of Youngiibacter in a similar way to how they do for Geobacter (Liu et al., 2015; Wang et al., 2018) facilitating electron transfer to syntrophic partner methanogens.

\section{Conductive-particle mediated syntrophy}

Syntrophy mediated by conductive particles could occur in three different ways (Fig. 7). A first mode of action includes electrogens with limited expression of surface cytochromes whose role would be replaced with that of conductive minerals (pyrite, pyrrhottite, magnetite, goethite) found in sediments (Fig. 7a). Molecular and microscopic evidence for this type of association has been brought by studies in laboratory Geobacter co-cultures provided with magnetite (Liu et al., 2015). A second possibility is that cells plug into macro-sized conductive rocks (i.e. iron/manganese-nodules) with one cell releasing electrons onto the rock and the other receiving electrons (Fig. 7b). Evidence for such interactions was previously obtained in laboratory co-cultures with macro-sized conductive chars. In this case, using SEM, it was shown that the electrogen $/ \mathrm{Ge}$ obacter did not require direct contact to the electrotroph/Methanosarcina yet the conductive surface facilitated the syntrophic association (Chen et al., 2014; Liu et al., 2012). The third possibility (Fig. 7c), is that membrane-bound proteins facilitate the precipitation of $\mathrm{Fe}^{2+}$-ions, e.g., with thiol groups (Milner-White \& Russell, 2005) to form a conductive surface-conduit surrounding the cell. Extracellular electron transfer between such mineral-coated cells has been proposed (Kato et al., 2012), but has not been confirmed. However, this could be a possibility for microbes without an extracellular apparatus for electron transfer to partner cells.

In evolutionary terms, it is plausible that mineral-mediated interactions preceded interspecies electron transfer interactions based in diffusible chemicals, which require complex enzymes and cell-bound electrical conduits. Primordial protocells had not developed enzymatic machineries to maintain redox and proton gradients across cell membranes (Martin et al., 2003; Russell et al., 1990, 1994; Wächtershäuser, 1988b). It has therefore been suggested that minerals, which can uphold voltage differences, such as FeS/pyrite, might have helped nucleate the earliest membranes, playing the role of early membrane-bound catalysts, instead of electron transport chain enzymes (Martin et al., 2003). Later, the high reactive iron content of the Archaean ocean could have promoted the formation of proteins with Fe-S centers which are required and abundant in redox proteins of methanogens (Liu et al., 2010). Here, we propose that primitive cells with leaky membranes (Lane \& Martin, 2012), allowed easy electron transfer via conductive minerals permitting energy exchange between separate metabolic protocell entities. Thus, conductive particles could have fostered the earliest interspecies interactions in the methanogenic and iron-rich Early Earth oceans, and possibly nurtured adaptation of interspecies associations pre-eukaryogenesis.

\section{CONCLUSION}

In conclusion, we show that the sediment of an early Earth ocean analogue is a niche for syntrophic associations dependent on conductive particles. Only if conductive particles were provided, could syntrophic bacteria coupled to methanogens oxidize their substrates. Thus, only in incubations with conductive particles, members of the genus Youngiibacter co-existed with Methanothrix. Incubations without conductive 
particles resulted in the disappearance of Youngiibacter, and one transfer later to the demise of the methanogenic community. These data indicate that conductive particles were required to aid the pairing of the metabolism of Youngiibacter with that of Methanothrix, which sustained high rates of methanogenesis in this early Earth analogue - lake La Cruz. We propose that obligate mineral-syntrophy is an ancestral interspecies interaction established before complex membrane structures and enzymes evolved to mediate direct or indirect associations between species with distinct metabolism.

\section{ACKNOWLEDGEMENTS}

This work is a contribution to a Danish Research Council grant 1325-00022 awarded to AER. During the writing of this manuscript, AER has been supported by three other grants: a Sapere Aude grant from Danish Research Council (4181-00203), a Novo Nordisk Foundation award and an Innovationsfonden grant (4106-00017), CRL was supported by the EU's H2020 program (\#704272, NITROX). NP thanks the Seventh Framework Programme of the European Union Marie Skłodowska-Curie Intra-European Fellowships (BioCTrack 330064) for their support. JT acknowledges support from a NERC research studentship. We would like to acknowledge lab support by Lasse Ørum-Smidt, Erik Laursen, Heidi Grøn Jensen, Bente Hølbeck, and Susanne Møller. Special thanks to the Limnology team of the University of Valencia for their help in the field and laboratory work during the sampling days.

\section{REFERENCES}

ADHIKARI, R. Y., N. S. MALVANKAR, M. T. TUOMINEN \& D. R. LOVLEY. 2016. Conductivity of individual Geobacter pili. RSC Advances, 6, 8354-8357. DOI: 10.1039/C5RA28092C

AHN, J., W.-S. JEONG, M.-Y. CHOI, B.-Y. KIM, J. SONG, \& H.-Y. WEON. 2014. Phylogenetic diversity of dominant Bacterial and Archaeal communities in plant-microbial fuel cells using rice plants. Journal of Micro- biology and Biotechnology, 24, 1707-1718. BECKMANN, S., M. KRÜGER, B. ENGELEN, A. A. GORBUSHINA, \& H. CYPIONKA. 2011. Role of bacteria, archaea and fungi involved in methane release in abandoned coal mines. Geomicrobiology, J. 28, 347-358. DOI: $10.1080 / 01490451.2010 .503258$

BLANEY, L. 2012. Magnetite (Fe3O4): properties, synthesis and applications. Lehigh Review, 15-2007, 208-211. DOI: 10.1016/j.ceramint.2011.11.027

BOSCH, J., K. LEE, G. JORDAN, K. KIM \& R. U. MECKENSTOCK. 2012. Anaerobic, nitrate-dependent oxidation of pyrite nanoparticles by Thiobacillus denitrificans. Environmental Science \& Technology, 46, 2095-2101. DOI: 10.1021/es2022329

BRAY, M. S., J. WU, B. C. REED, C. B. KRETZ, K. M. BELLI, R. L. SIMISTER, et al. 2017. Shifting microbial communities sustain multiyear iron reduction and methanogenesis in ferruginous sediment incubations. Geobiology, 15, 678-689. DOI: 10.1111/gbi. 12239

BURA-NAKIC, E., E. VIOLLIER, D. JÉZÉQUEL, A. THIAM, \& I. CIGLENECKI. 2009. Reduced sulfur and iron species in anoxic water column of meromictic crater Lake Pavin (Massif Central, France). Chemical Geology, 266, 311-317. DOI: 10.1016/ j.chemgeo.2009.06.020

CAMACHO, A., R. MIRACLE, L. ROMERO-VIANA, A. PICAZO, \& E. VICENTE. 2017. Lake La Cruz, an iron-rich karstic meromictic lake in central Spain. In Ecology of Meromictic Lakes, 187-233. DOI: 10.1007/978-3-319-49143-1

CANFIELD, D. E., R. RAISWELL, J. T. WESTRICH, C. M. REAVES, \& R. A. BERNER. 1986. The use of chromium reduction in the analysis of reduced inorganic sulfur in sediments and shales. Chemical Geology, 54, 149-155. DOI: 10.1016/0009-2541(86) 90078-1

CAPORASO, J. G., J. KUCZYNSKI, J. STOMBAUGH, K. BITTINGER, F. D. BUSHMAN, E. K. COSTELLO, et al. 2010. QIIME allows analysis of high-throughput community sequencing data. Nature Methods, 7, 335. 
CHEN, S., A.-E. ROTARU, P. M. SHRESTHA, N. S. MALVANKAR, F. LIU, W. FAN, et al. 2014. Promoting interspecies electron transfer with biochar. Scientific Reports, 4, 5019. DOI: $10.1038 /$ srep05019

CHOJNACKA, A. \& K. B. 2015. Noteworthy facts about a methane- producing microbial community processing acidic effluent from sugar beet molasses fermentation. PLoS One, 1-23. DOI: 10.1371/journal.pone.0128008

COMAN, C., B. DRUGA, A. HEGEDUS, C. SICORA, \& N. DRAGOS. 2013. Archaeal and bacterial diversity in two hot spring microbial mats from a geothermal region in Romania. Extremophiles, 17: 523-534. DOI: 10.1007/s00792-013-0537-5

CROWE, S. A., C. JONES, S. KATSEV, A. H. O. NEILL, A. STURM, D. E. CANFIELD, et al. 2008. Photoferrotrophs thrive in an Archean Ocean analogue. Proceedings of the National Academy of Sciences, 105: 15938-15943.

CROWE, S. A., S. KATSEV, K. LESLIE, A. STURM, C. MAGEN, S. NOMOSATRYO, et al. 2011. The methane cycle in ferruginous Lake Matano. Geobiology, 9: 61-78. DOI: 10.1111/j.1472-4669.2010.00257.x

DINH, H. T., J. KUEVER, M. MUßMANN, A. W. HASSEL, M. MUSSMAN, A. W. HASSEL, et al. 2004. Iron corrosion by novel anaerobic microorganisms. Nature, 427: 829-832. DOI: 10.1038/nature02321

DRIDI, B., M. FARDEAU, B. OLLIVIER, D. RAOULT \& M. DRANCOURT. 2012a. Methanomassiliicoccus luminyensis gen. nov., sp. nov., a methanogenic archaeon isolated from human faeces. International Journal of Systematic and Evolutionary Microbiology, 62: 1902-1907. DOI: 10.1099/ijs.0.033712-0

DRIDI, D. I. S., M. HENRY, J. MOULIN, M. CEDEX, \& M. DRANCOURT. 2012b. Age-related prevalence of Methanomassiliicoccus luminyensis in the human gut microbiome. Acta Pathologica, Microbiologica et Immunologica Scandinavica, 120:773-777. DOI: 10.1111/j.1600-0463.2012.02899.x

DUBA, A. G. 1977. Electrical conductivity of coal and coal char. Fuel, 56:441-443.

EMBREE, M., H. NAGARAJAN, N. MOVAHEDI, H. CHITSAZ, \& K. ZENGLER. 2014.
Single-cell genome and metatranscriptome sequencing reveal metabolic interactions of an alkane-degrading methanogenic community. ISME Journal, 8: 757-67. DOI: 10.1038/ ismej.2013.187

GREGORY, K. B., D. R. BOND, \& D. R. LOVLEY. 2004. Graphite electrodes as electron donors for anaerobic respiration. Environmental Microbiology. 6: 596-604. DOI: 10.1111/j.1462-2920.2004.00593.x

GUSKOS, N., G. J. PAPADOPOULOS, V. LIKODIMOS, S. PATAPIS, D. YARMIS, A. PRZEPIERA, et al. 2002. Photoacoustic, EPR and electrical conductivity investigations of three synthetic mineral pigments: hematite, goethite and magnetite. Materials Research Bulletin, 37: 1051-1061. DOI: 10.1016/S0025-5408(02)00742-0

HE, S., S. L. R. STEVENS, L.-K. CHAN, S. BERTLISSON, T. GLAVINA DEL RIO, S. G. TRINGE, et al. 2017. Ecophysiology of freshwater Verrucomicrobia inferred from metagenome-assembled genomes. mSphere, 2: 1-17. DOI: 10.1128/mSphere.00277-17

HOLMES, D. E., P. M. SHRESTHA, D. J. F. WALKER, Y. DANG, K. P. NEVIN, T. L. WOODARD D. R. LOVLEY. 2017. Metatranscriptomic evidence for direct interspecies electron transfer between Geobacter and Methanothrix species in methanogenic rice paddy soils. Applied Environmental Microbiology, 83 (9), e00223-17. DOI: 10.1128/ AEM.00223-17

KADNIKOV, V. V, Y. A. FRANK, A. V. MARDANOV, A. V. BELETSKY, D. A. IVASENKO \& N. V. PIMENOV. 2017. Variability of the composition of the microbial community of the deep subsurface thermal aquifer in western Siberia. Microbiology, 86:765-772. DOI: $10.1134 / \mathrm{S} 002626171706008 \mathrm{X}$

KASTENING, B., M. HAHN, B. RABANUS, M. HEINS \& U. FELDE. 1997. Electronic properties and double layer of activated carbon. Electrochimica Acta, 42: 2789-2800.

KATO, S., K. HASHIMOTO \& K. WATANABE. 2012. Microbial interspecies electron transfer via electric currents through conductive minerals. Proceedings of the National Academy of Sciences, 109, 10042-10046. 
DOI: $10.1073 /$ pnas.1117592109

KATO, S. \& K. IGARASHI. 2018. Enhancement of methanogenesis by electric syntrophy with biogenic iron-sulfide minerals. Microbiology Open, e00647. DOI: 10.1002/mbo3.647

KAWAICHI, S., N. ITO, R. T. KAMIKAWA, SUGAWARA, T. YOSHIDA \& Y. SAKO. 2013. Ardenticatena maritima gen. nov., sp. nov., a ferric iron- and nitrate-reducing bacterium of the phylum 'Chloroflexi' isolated from an iron-rich coastal hydrothermal field, and description of Ardenticatenia classis nov. International Journal of Systematics and Evolutionary Microbiology, 63: 2992-3002. DOI: 10.1099/ijs.0.046532-0

KAWAICHI, S., T. YAMADA, A. UMEZAWA, S. MCGLYNN, T. SUZUKI, N. DOHMAE, et al. 2018. Anodic and cathodic extracellular electron transfer by the filamentous bacterium Ardenticatena maritima. Frontiers in Microbiology, 9: 1-11. DOI: 10.3389/fmicb.2018. 00068

KEARSE, M., R. MOIR, A. WILSON, S. STONES-HAVAS, M. CHEUNG, S. STURROCK, et al. 2012. Geneious Basic: an integrated and extendable desktop software platform for the organization and analysis of sequence data. Bioinformatics, 28: 1647-1649. DOI: 10.1093/bioinformatics/ bts199

KLINDWORTH, A., E. PRUESSE, T. SCHWEER, J. PEPLIES, C. QUAST, M. HORN, et al. 2013. Evaluation of general 16S ribosomal RNA gene PCR primers for classical and next-generation sequencing-based diversity studies. Nucleic Acids Research, 41: 1-11. DOI: $10.1093 / \mathrm{nar} / \mathrm{gks} 808$

KONDO, K., A. OKAMOTO, K. HASHIMOTO \& R. NAKAMURA. 2015. Sulfur-mediated electron shuttling sustains microbial long-distance extracellular electron transfer with the aid of metallic iron sulfides. Langmuir, 31: 7427-7434. DOI: 10.1021/acs.langmuir. $5 \mathrm{~b} 01033$

LAIR, V., H. ANTONY, L. LEGRAND \& A. CHAUSSÉ. 2006. Electrochemical reduction of ferric corrosion products and evaluation of galvanic coupling with iron. Corrosion Science, 48, 2050-2063. DOI: 10.1016/j.corsci.
2005.06 .013

LANE, N. \& W. F. MARTIN. 2012. The origin of membrane bioenergetics. Cell, 151: 1406-1416. DOI: 10.1016/j.cell.2012.11.050

LAWSON, P. A., B. WAWRIK, T. D. ALLEN, C. N. JOHNSON, C. R. MARKS, R. S. TANNER, et al. 2014. Youngiibacter fragilis gen. nov., sp. nov., isolated from natural gas production-water and reclassification of Acetivibrio multivorans as Youngiibacter multivorans comb. nov. International Journal of Systematics and Evolutionary Microbiology, 64: 198-205. DOI: 10.1099/ijs.0.053728-0

LIU, F., A.-E. ROTARU, P. M. SHRESTHA, N. S. MALVANKAR, K. P. NEVIN \& D. R. LOVLEY. 2012. Promoting direct interspecies electron transfer with activated carbon. Energy Environental Science, 5, 8982. DOI: $10.1039 / \mathrm{c} 2 \mathrm{ee} 22459 \mathrm{c}$

LIU, F., A.-E. ROTARU, P. M. SHRESTHA, N. S. MALVANKAR, K. P. NEVIN \& D. R. LOVLEY. 2015. Magnetite compensates for the lack of a pilin-associated c-type cytochrome in extracellular electron exchange. Environmental Microbiology, 17: 648-55. DOI: 10.1111/1462-2920.12485

LIU, Y., M. SIEPRAWSKA-LUPA, W. B. WHITMAN \& R. H. WHITE. 2010. Cysteine is not the sulfur source for iron-sulfur cluster and methionine biosynthesis in the methanogenic archaeon Methanococcus maripaludis. Journal of Biological Chemistry, 285: 31923-31929. DOI: 10.1074/jbc.M110. 152447

LLIRÓS, M., T. GARCÍA-ARMISEN, F. DARCHAMBEAU, C. MORANA, X. TRIADÓ-MARGARIT, Ö. INCEOĞLU, et al. 2015. Pelagic photoferrotrophy and iron cycling in a modern ferruginous basin. Scientific Reports, 5, 13803. DOI: 10.1038/srep13803

LÓPEZ-GARCÍA，P. \& D. MOREIRA. 1999. Metabolic symbiosis at the origin of eukaryotes. Trends in Biochemical Sciences, 24: 88-93.

LOVLEY, D. R. \& E. J. P. PHILLIPS. 1987. Rapid assay for microbially reducible ferric iron in aquatic sediments. Applied and Environmental Microbiology, 53, 1536-1540.

LOVLEY, D. R., E. E. RODEN, E. J. P. 
PHILLIPS \& J. C. WOODWARD. 1993. Enzymatic iron and uranium reduction by sulfate-reducing bacteria. Marine Geology, 113: 41-53.

MAHADEVAN, A. \& S. FERNANDO. 2018. Inorganic iron-sulfur clusters enhance electron transport when used for wiring the NAD-glucose dehydrogenase based redox system. Microchimica Acta, 2: 1-8.

MARTIN, W., M. J. RUSSELL, D. HORNER, R. BLANKENSHIP, T. CAVALIER-SMITH \& E. NISBET. 2003. On the origins of cells : a hypothesis for the evolutionary transitions from abiotic geochemistry to chemoautotrophic prokaryotes, and from prokaryotes to nucleated cells. Philosophical Transactions of the Royal Society London B, 358: 59-85. DOI: 10.1098/rstb.2002.1183

MILNER-WHITE, E. J. \& M. J. RUSSELL. 2005. Sites for phosphates and iron-sulfur thiolates in the first membranes: 3 to 6 residue anion-binding motifs (nests). Origins of Life and Evolution of Biospheres, 35: 19-27.

MIRACLE, M. R., E. VICENTE \& C. PEDROS-ALIO. 1992. Biological studies of spanish meromictic and stratified karstic lakes. Limnetica, 8, 59-77.

MOREIRA, D. \& P. LOPEZ-GARCIA. 1998. Symbiosis between methanogenic Archaea and delta-Proteobacteria as the origin of Eukaryotes : the syntrophic hypothesis. Journal of Molecular Evolution, 47: 517-530.

MORITA, M., N. S. MALVANKAR, A. E. FRANKS, Z. M. SUMMERS, L. GILOTEAUX, A. E. ROTARU, et al. 2011. Potential for direct interspecies electron transfer in methanogenic wastewater digester aggregates. MBio 2, e00159-11. DOI: 10.1128/ mBio.00159-11

NAKASONO, S., N. MATSUMOTO \& H. SAIKI. 1997. Electrochemical cultivation of Thiobacillus ferrooxidans by potential control. Bioelectrochemistry and Bioenergetics, 43: 61-66.

NORDI, K. Á., B. THAMDRUP \& C. J. SCHUBERT. 2013. Anaerobic oxidation of methane in an iron-rich Danish freshwater lake sediment. Limnology \& Oceanography, 58: 546-554. DOI: 10.4319/1o.2013.58.2.0546
OSWALD, K., C. JEGGE, J. TISCHER, J. BERG, A. BRAND, M. R. MIRACLE, et al. 2016. Methanotrophy under versatile conditions in the water column of the ferruginous meromictic lake La Cruz (Spain). Frontiers in Microbiology, 7: 1-16. DOI: 10.3389/fmicb. 2016.01762

PARK, J., B. LEE, P. SHI, H. KWON, S. JEONG \& H. JUN. 2018. Methanol metabolism and archaeal community changes in a bioelectrochemical anaerobic digestion sequencing batch reactor with copper-coated graphite cathode. Bioresource Technology, 259: 398-406. DOI: 10.1016/j.biortech.2018.03.009

PARKHOMENKO, E. I. 1990. Electrical properties of rocks and minerals. In Electrical properties of rocks (Cambridge: Cambridge University Press).

PAUL, K., J. O. NONOH, L. MIKULSKI \& A. BRUNE. 2012. "Methanoplasmatales," Thermoplasmatales-related Archaea in termite guts and other environments, are the seventh order of methanogens. Applied and Environmental Microbiology, 78: 8245-8253. DOI: 10.1128/AEM.02193-12

PEARCE, C. I., A. D. PATTRICK \& D. J. VAUGHAN. 2006. Electrical and magnetic properties of sulfides. Reviews in Mineralogy and Geochemistry, 61: 127-180. DOI: 10.2138/ rmg.2006.61.3

POSTH, N. R., L. A. BRISTOW, R. P. COX, K. S. HABICHT, F. DANZA, M. TONOLLA, et al. 2017. Carbon isotope fractionation by anoxygenic phototrophic bacteria in euxinic Lake Cadagno. Geobiology, 15: 798-816. DOI: $10.1111 / \mathrm{gbi} .12254$

POULTON, S. W. \& R. RAISWELL. 2002. The low-temperature geochemical cycle of iron: from continental fluxes to marine sediment deposition. American Journal of Science, 302: 774-805.

POULTON, S. W., M. D. KROM \& R. RAISWELL. 2004. A revised scheme for the reactivity of iron (oxyhydr)oxide minerals towards dissolved sulfide. Geochimica et Cosmochimica Acta, 68: 3703-3715. DOI: 10.1016/j.gca.2004.03.012

POULTON, S. W. \& D. E. CANFIELD. 2005. Development of a sequential extraction proce- 
dure for iron: Implications for iron partitioning in continentally derived particulates. Chemical Geology, 214: 209-221. DOI: 10.1016/j.chemgeo.2004.09.003

POUS, N., C. KOCH, J. COLPRIM, S. PUIG \& F. HARNISCH. 2014. Extracellular electron transfer of biocathodes: revealing the potentials for nitrate and nitrite reduction of denitrifying microbiomes dominated by Thiobacillus sp . Electrochemistry Communications, 49: 93-97. DOI: 10.1016/j.elecom.2014.10.011

ROCHELLE, C. M. \& U. SCHWERTMANN. 2003. The iron oxides: structure, properties, reactions, occurrences and uses. In The iron oxides: structure, properties, reactions, occurrences and uses, $5-18$.

ROMERO-VIANA, L., R. JULIÀ, M. SCHIMMEL, A. CAMACHO, E. VICENTE \& M. R. MIRACLE. 2011. Reconstruction of annual winter rainfall since A.D. 1579 in central-eastern Spain based on calcite laminated sediment from Lake La Cruz. Climate Change, 107: 343-361. DOI: 10.1007/s10584-010-9966-7

ROTARU, A.-E., P. M. SHRESTHA, F. LIU, M. SHRESTHA, D. SHRESTHA, M. EMBREE, et al. 2014a. A new model for electron flow during anaerobic digestion: direct interspecies electron transfer to Methanosaeta for the reduction of carbon dioxide to methane. Energy \& Environmental Science, 7, 408. DOI: $10.1039 / \mathrm{c} 3$ ee42189a

ROTARU, A.-E., P. M. SHRESTHA, F. LIU, B. MARKOVAITE, S. CHEN, K. P NEVIN, et al. 2014b. Direct interspecies electron transfer between Geobacter metallireducens and Methanosarcina barkeri. Applien and Environmental Microbiology, 80: 4599-605. DOI: 10.1128/AEM.00895-14

ROTARU, A.-E., T. L. WOODARD, K. P. NEVIN \& D. R. LOVLEY. 2015. Link between capacity for current production and syntrophic growth in Geobacter species. Frontier in Microbiology, 6, 744. DOI: 10.3389/fmicb.2015.00744

ROTARU, A.-E., F. CALBRESE, H. STRYHANYUK, F. MUSAT, P. M. SHRESTHA, H. S.WEBER, et al. 2018. Conductive particles enable syntrophic acetate oxidation between Geobacter and Methanosarcina from coastal sediments. MBio, 9, 1-14.

RUSSELL, M. J., A. J. HALL \& A. P. GIZE. 1990. Pyrite and the origin of life. Nature, 344, 387.

RUSSELL, M. J., R. M. DANIEL, A. J. HALL \& J. A. SHERRINGHAM. 1994. A hydrothermally precipitated catalytic iron sulphide membrane as a first step toward life. Journal of Molecular Evolution, 39: 231-243. DOI: 10.1007/BF00160147

SALGADO-FLORES, A., M. BOCKWOLDT, L. H. HAGEN, P. B. POPE \& A. SUNDSET. 2016. First insight into the faecal microbiota of the high Arctic muskoxen (Ovibos moschatus). Microbial Genomics, 2 (7), e000066. DOI: $10.1099 / \mathrm{mgen} .0 .000066$

SHRESTHA, P. M., A.-E. ROTARU, Z. M. SUMMERS, M. SHRESTHA, F. LIU \& D. R.LOVLEY. 2013. Transcriptomic and genetic analysis of direct interspecies electron transfer. Applied and Environmental Microbiology, 79:2397-2404. DOI: 10.1128/AEM. 03837-12

SHRESTHA, P. M. \& A.-E. ROTARU. 2014. Plugging in or going wireless: strategies for interspecies electron transfer. Frontiers in Microbiology, 5, 237. DOI: 10.3389/fmicb. 2014.00237

SUMMERS, Z. M., H. E. FOGARTY, C. LEANG, A. E. FRANKS, N. S. MALVANKAR \& D. R. LOVLEY. 2010. Direct exchange of electrons within aggregates of an evolved syntrophic coculture of anaerobic bacteria. Science, 330: 1413-1415. DOI: 10.1126/science. 1196526

TANAKA, K., K. NAKAMURA \& E. MIKAMI. 1991. Fermentation of cinnamate by a mesophilic strict anaerobe, Acetivibrio multivorans sp. nov. Archives of Microbiology, 155: 120-124.

THOMPSON, J. 2018. Iron and phosphorus cycling under ferruginous conditions. Ph.D. Thesis. University of Leeds, UK.

UEKI, T., K. P. NEVIN, A.-E. ROTARU, L. WANG, J. E. WARD, T. L. WOODARD, et al. 2018. Geobacter strains expressing poorly conductive pili reveal constraints on direct interspecies electron transfer. MBio, 9. DOI: 10.1128/mBio.01273-18 
VICENTE, E. \& M. MIRACLE. 1988. Physicochemical and microbial stratification in a meromictic karstic lake of Spain. Verhandlungen des Internationalen Verein Limnologie, 23: 522-529.

WÄCHTERSHÄUSER, G. 1988a. Before enzymes and templates: theory of surface metabolism. Microbiological Reviews, 52: 452-484.

WÄCHTERSHÄUSER， G. 1988b. Pyrite Formation, the First Energy Source for Life: a Hypothesis. Systematic and Applied Microbiology, 10: 207-210. DOI: 10.1016/S07232020(88)80001-8

WALKER, D. J. F., R. Y. ADHIKARI, D. E. HOLMES, J. E. WARD, L. TREVOR, K. P. NEVIN, et al. 2018. Electrically conductive pili from pilin genes of phylogenetically diverse microorganisms. ISME Journal, 12: 48-58. DOI: 10.1038/ismej.2017.141

WALTER, X. A., A. PICAZO, M. R. MIRACLE, E. VICENTE, A. CAMACHO, M. ARAGNO, et al. 2014. Phototrophic Fe(II)-oxidation in the chemocline of a ferruginous meromictic lake. Frontiers in Microbiology, 5: 1-9. DOI: 10.3389/fmicb.2014.00713

WANG, L., K. P. NEVIN, T. L. WOODARD, B. MU \& D. R. LOVLEY. 2016. Expanding the diet for DIET: Electron donors supporting direct interspecies electron transfer (DIET) in defined co-cultures. Frontiers in Microbiology: 7, 1-7. DOI: 10.3389/fmicb.2016.00236

WANG, O., S. ZHENG, B. WANG \& W. WANG. 2018. Necessity of electrically conductive pili for methanogenesis with magnetite stimulation. PeerJ, 2: 1-14. DOI: 10.7717/peerj. 4541

ZEGEYE, A., S. BONNEVILLE, L. G. BENNING, A. STURM, D. A. FOWLE, C. A. JONES, et al. 2012. Green rust formation controls nutrient availability in a ferruginous water column. Geology, 40: 599-602. DOI: 10.1130/G32959.1

ZHENG, S., B. WANG, F. LIU \& O. WANG. 2017. Magnetite production and transformation in the methanogenic consortia from coastal riverine sediments. Journal of Microbiology, 55: 862-870. DOI: 10.1007/s12275-017$7104-1$

Con el apoyo de:
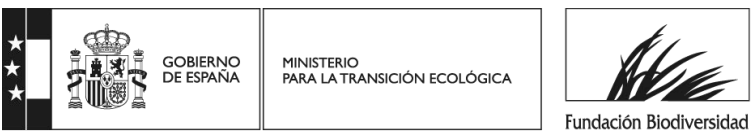